Edited by Manuel Alcántara, Daniel Buquet, and

María Laura Tagina

\title{
Elecciones y partidos en América Latina en el cambio del ciclo
}

Madrid: Centro de Investigaciones Sociológicas, 2018, p. 511.

Ryan E. Carlin ${ }^{1}$

Between 2013 and the first quarter of 2017 every Latin American electoral democracy held legislative and, with the exception of Mexico, presidential elections. On the heels of a region-wide swing to the political left, many observers wondered what next might be in store. But it was almost a given that elections remained the only legitimate pathway power in the region during this period. Elections had become institutionalized in Latin America. Hence, the 20132017 election cycle granted as good an opportunity as any to take stock of party-system dynamics and representation in the region.

This opportunity was not lost on Manuel Alcántara, Daniel Buquet, and Maria Laura Tagina, editors of Elecciones y partidos en América Latina en el cambio del ciclo (2018, 7).These accomplished scholars compiled twenty chapters spanning all eighteen electoral democracies in Latin America from 2013 to 2017. As stated in their introductory chapter, the book's goal is to focus on "las transformaciones acaecidas en los respectivos sistemas de partidos a lo largo de las últimas décadas" and the extent to which, "marcaron un punto de inflexión... respecto de su desarrollo previo, o bien confirmaron tendencias preexistentes" (7).To undertake such a massive endeavor, the editors enlisted country experts from the ranks of doctoral students up to some of the most renowned political scientists in the region. The result is an extremely rich collection of essays that helps stu-

${ }^{1}$ Georgia State University. 
dents of the region appreciate patterns of change within and between countries in the 2013-2017 cycle.

My review analyzes three central aspects of the volume: (a) comparative approach; (b) theoretical puzzle; and (c) theoretical-conceptual innovation. Let us consider each in turn.

\section{Comparative Approach}

Tracking party-system and electoral change in eighteen Latin American electoral democracies over four decades requires organization and coordination across contributors so that spatial and temporal patterns stand out. To that end, the introductory chapter by the editors ("Introducción"), Alcántara, Buquet, and Tagina, lays out a common set of metrics and defines the empirical scope of the chapters, each a case study. This is no simple task but an essential one for the sake of comparative analysis.

The metrics used consistently throughout the volume were meant to tap basic elements of party systems and electoral competition. Among the former are Rae's ${ }^{2}$ index of fragmentation, Laakso and Taagepera's ${ }^{3}$ effective number of parties (ENPP), and Jones and Mainwaring's (2003) index of party system nationalization. Electoral competition indicators refer to Pedersen's ${ }^{4}$ volatility index, electoral concentration and electoral competitiveness ${ }^{5}$ (Ocaña and Oñate, 1999), and left-right ideological location and polarization based on data from the Proyecto Élites Legislativas

\footnotetext{
${ }^{2}$ Douglas W. Rae (1967). The Political Consequences of Electoral Laws. New Haven: Yale University Press.

${ }^{3}$ Markku Laakso and Rein Taagepera (1979). "'Effective' Number of Parties: A Measure with Application to West Europe." Comparative Political Studies 12, $\mathrm{N}^{\circ} 1: 3-27$.

${ }^{4}$ Mogens N. Pedersen (1979). "The Dynamics of European Party Systems: Changing Patterns of Electoral Volatility." European Journal of Political Research 7, $\mathrm{N}^{\circ}$ 1: 1-26.

${ }^{5}$ Pablo Oñate and Francisco Ocaña (1999). "Índices e indicadores del sistema electoral y del sistema de partidos: Una propuesta informática para su cálculo." Revista Española de Investigaciones Sociológicas: 233-245.
} 
de América Latina of the University of Salamanca (PELA). Armed with these metrics, contributors could draw inferences about the transformations within and across party systems over time.

Beyond metrics, each case study reports on three sets of representation outcomes of interest to a wide range of scholars and students. The first set of outcomes relates to the implications of party-system change and electoral dynamics for executive-legislative relations. A second concerns how party systems and electoral competition have affected women's representation. Thirdly, patterns of electoral participation are reported. Finally, the authors discuss the potential challenges for governability each scenario presents. While more speculative, these reflections add depth to the analyses and, with hindsight, give readers a sense of the challenges of prediction.

Establishing this common framework of themes gives essential structure to each chapter and goes a long way towards facilitating systematic analysis within and across cases. The editors accomplish this in their introductory chapter by providing a cross-sectional view of party systems and electoral competition in the 2013-2017 electoral cycle. Indeed, these descriptive results constitute one of the most important contributions of the book and will be an enduring resource to observers of Latin American politics.

Let us briefly report some of their central findings. Party system fragmentation increased in two-thirds of the countries under study, bookended by Brazil (13.3 ENPP) and Nicaragua's hegemonic system (1.61 ENPP). Moderate pluralism is predominant, present in half of the eighteen cases. Bipartisan systems, while not extinct, are a rara avis (10), present only in Bolivia. The rest of the systems feature robust multipartyism.

Elections during Latin America's 2013-2017 cycle ranged widely in concentration and competitiveness. Regarding the former, the percentage of the first-round presidential vote for the top two candidates was extremely 
high in Venezuela (99.7\%), El Salvador (87.9\%), Nicaragua $(87.5 \%)$, and Bolivia (85.6\%) and relatively low in Guatemala (43.6\%), Colombia (54.9\%), and Costa Rica (60.3\%). Competitiveness in presidential contests varied from razor thin margins between the top two first-round candidates in Venezuela $(0.5 \%)$ and Costa Rica $(0.9 \%)$ to landslides in Nicaragua (57.4\%) and Bolivia (37.1\%). Altogether, alternation of power from the incumbent to the opposition party or coalition was experienced in seven of the eighteen countries in the region. The editors build on this evidence in the conclusion and offer suggestive evidence that alternation might be the missing link between party systems and electoral dynamics, on one hand, and democratic and party system institutionalization, on the other hand. We shall return to this point below.

Ideologically, the 2013-2017 election cycle produced a 50-50 split between leftist and rightist presidents. Whereas two leftists passed the presidential sash to a rightist -Cristina Fernández to Mauricio Macri in Argentina, and Ollanta Humala to Pedro Pablo Kuczinski in Peru- rightists were succeeded by leftists in the same number of instances -Laura Chinchilla to Luis Guillermo Solís in Costa Rica and Sebastián Piñera to Michelle Bachelet in Chile (12-13, Table 1.3). To speak of "right turn" in this cycle was, as the editors acknowledge, clearly premature.

When it comes to the representation, the editors' introductory chapter documents the governing dynamic between executives and the legislature. In 2016, the government enjoyed a partisan majority in congress in Bolivia, Honduras, Ecuador, Nicaragua, Paraguay, Dominican Republic, and Uruguay. Yet governments in eight Latin American countries were led by more precarious, minority governments. Three other governments had cobbled together majority coalitions (Brazil, Colombia, and Chile). Clearly, the region's government enjoyed varying degrees of leverage and latitude for advancing their agendas in this period. 
Lastly, women's representation saw some major gains during the 2013-2017 cycle via the implementation of affirmative action laws. Specifically, gender parity laws went into effect in Bolivia (2014), Costa Rica (2014), and Mexico (2015) with diverging results. Gender quota laws took effect in El Salvador (2013) and Uruguay (2015) (see pp. 16-17).

Together, this massive compilation of data nicely summarizes the state of party systems and electoral competition in Latin America. The introductory chapter also reports on electoral participation and voting from abroad which, while interesting, felt detached from the overall theme. One could even argue that the discussion of women's representation might well have been excluded on grounds of coherence. Unfortunately, the chapter ends without a conclusion that could have helped to justify these decisions to the reader.

\section{Theoretical Puzzle}

Luckily for the reader, however, the editors conclude the volume with a theoretically robust chapter ("Elecciones, ciclos políticos y alternancia en América Latina"). Tellingly, this title does not refer to any sort of "conclusions," but indeed tips the editors' hand about the volume's main theoretical developments.

The editors' goals for the concluding chapter are threefold. First, they intend to compare party system dynamics and patterns of electoral competition for the region over time. Second, they seek to unpack the implications of these patterns for the processes of democratization in the Latin American context. And, third, they offer "alternation" as a new lens through which to view and evaluate -and potentially link- these processes. We will be returning to this in the final section of the review.

Regarding the first goal, the editors note that between the last two decades of the twentieth century and the first two decades of the twenty-first century, rates of electoral volatility have changed quite a bit across countries but have 
remained, on average, at the same very high level for the region as a whole. Party systems, however, have tended to become more fragmented since 2000. Looking at the most democratic cases in the region, however, they unearth their main theoretical puzzle (482-484).

Seminal theorizing by Sartori, ${ }^{6}$ and Mainwaring and Scully $(1995)^{7}$ posited that democracy's prospects were helped by low levels of volatility, low degrees of party system fragmentation, and low levels of polarization. Yet Alcántara, Buquet, and Tagina's inductive analyses reveal strong democracies and institutionalized party systems namely, Brazil, Chile, and Uruguay- coexisting and even thriving with highly fragmented and highly polarized systems. Hence, the editors identify a theoretical puzzle or, at the very least, a tension between theory and reality in Latin America.

\section{Theoretical-Conceptual Innovation}

Attempting to solve this puzzle, the editors posit alternation in executive power as an alternative indicator of the prospects of democracy in Latin America's presidential systems. Alternation is defined as "Obtención del cargo tras la celebración de elecciones, por una fórmula política distinta a la que estaba en el poder... Una fuerza política, bajo el nombre de partido político o de gran coalición o alianza sociopolítica, reemplaza a otra diferente" (Alcántara, Buquet and Tagina, 2018, 489). Such a clear definition should be applauded. It nevertheless runs the risk of eliding election outcomes and party system outputs with a once-common criterion for democratic competition itself, i.e. alternation.

\footnotetext{
${ }^{6}$ Giovanni Sartori (1976). Party and Party Systems. A Framework for Analysis. Cambridge: Cambridge University Press.

${ }^{7}$ Scott Mainwaring and Timothy R. Scully (1995). "Introduction: Party Systems in Latin America." In Scott Mainwaring and Timothy R. Scully (eds.), Building Democratic Institutions: Party Systems in Latin America. Stanford: Stanford University Press, pp. 1-34.
} 
Alcántara, Buquet, and Tagina proceed to code alternation for each election in the sample (Table 20.2, p. 490). From this empirical analysis, they observe that alternation peaked with the "left turn" and has decreased since then. Contrary to a naïve economic voting prediction, the authors reject economic performance as the driver of alternation in the region. If anything, alternation is more prevalent among countries experiencing rapid economic growth (491-493). Alternation is also higher in cases that allow for immediate reelection of the president. This would also seem to caution against a facile "mechanical" explanation, since reelection would presumably decrease alternation.

Stymied in their attempt to account for alternation, the analysts ask how alternation might be related to party system dynamics, electoral competition, and, ultimately, democratic outcomes. They uncover some non-obvious several non-linearities. Namely, alternation is more prevalent at high and low levels of volatility and polarization and less prevalent at high and low levels of fragmentation. Perhaps not surprisingly, then, moderate levels of alternation -between $43 \%$ and $63 \%$ of the time- are associated with high degrees of party system institutionalization and Freedom House composite measures of democracy. Exactly how these factors are causally linked is not explored. Nonetheless, identifying these associations constitutes a contribution that will fuel debates going forward.

\section{On Balance}

This edited work by Alcántara, Buquet, and Tagina makes an important contribution. It goes beyond previous works in this genre to systematize metrics, impose a clear structure, and repurpose a new concept -alternation- to help understand how party systems and electoral competition might influence democratic stability and party system institutionalization. Although the editors do not state it explicitly, alternation may be the missing link between these political 
inputs and normatively appealing system outputs.The individual case-study chapters, to which I could not possibly do justice, given space constraints, merit a close read. Not only are they engaging, but also rich with data and consistent enough in format to facilitate comparisons within and between cases.

In this reviewer's opinion, the book's theoretical impact would have been strengthened by incorporating the theoretical puzzle and the notion that alternation might be related to regime-level outcomes into the framework starting in the introductory chapter. That would have allowed, in turn, chapter contributors to grapple with these elements in their case studies. I suspect this would have granted the volume additional empirical insights, as well. As it stands, the volume straddles the line between an outstanding empirical reference text and a work that advances our understanding of the role party systems and electoral competition play in strengthening democratic stability. On the first score it undoubtedly succeeds; on the second, it takes some crucial first steps that pave the way for future research.

In sum, Alcántara, Buquet, Tagina, and colleagues deserve much credit for documenting four decades of party system dynamics and electoral competition, and moving forward the conversation about how they matter for democracy. It is a must-read book for students of party systems, electoral competition, and democracy in Latin America. And those who read it will surely wish to engage its fascinating findings. 